\section{Development of an analytical method for the determination of low-level of dioxin and furans in marine and freshwater species}

\author{
P.-L. Cloutier, ${ }^{1,3}$ F. Fortin, ${ }^{3}$ M. Fournier, ${ }^{2}$ \\ P. Brousseau, ${ }^{2}$ P.-É. Groleau, ${ }^{3}$ \\ M. Desrosiers ${ }^{1}$
}

${ }^{1}$ Centre d'expertise en analyse environnementale du Québec, ministère du

Développement durable, de

l'Environnement et de la Lutte contre les changements climatiques, Québec, QC; ${ }^{2}$ Institut National de la recherche scientifique - Institut Armand-Frappier (INRSIAF), Laval, QC; ${ }^{3}$ Centre d'expertise en analyse environnementale du Québec, ministère du Développement durable, de l'Environnement et de la Lutte contre les changements climatiques, Laval, QC, Canada

\section{Introduction}

Persistent organic pollutants (POPs) such as polychlorinated biphenyls (PCBs), polybrominated diphenyl ethers (PBDEs) and polychlorinated dibenzo- $p$-dioxins/furans (PCDD/ Fs) are well-known ubiquitous contaminants, persistent in the environment and could bioamplify in trophic food webs. ${ }^{1}$ These chemicals can induce important chemical stresses on the ecosystems and their monitoring is frequently realized in different environmental matrix, such as water, particulate matter, soils/sediments and biological samples. ${ }^{2-4}$

The interaction between pollution and climatic changes program (IPOC) proposed to use mussels as bioindicator species of freshwater and marine water quality. The species selected are dressenids (Dreissena bugensis and Dreissena polymorpha) for freshwaters and blue mussels (Mytilus edulis) for marine waters. Mussels are filter feeding organisms that bioaccumulate pollutant mainly by the ingestion of particulate matter. That is why mussels have been extensively used as sentinel species, especially for marine waters..$^{1,46}$ The filtration feeding can induce high levels of POPs in the organism while low concentrations of the pollutants are observed in water samples. Moreover, the levels measured in mussels may provide information of the bioavailable fraction of pollutants in the water column susceptible to induce adverse effects. ${ }^{4}$ Incidentally, biota are preferred matrix for pollution monitoring studies for POPs (PCBs, PBDEs and PCDD/Fs) in the EU
Directive 2008/105/EC. ${ }^{5}$

Biological samples, such as mussels and fish that have high lipid content, are commonly extracted by Soxhlet apparatus, digested with concentrated acid and submitted to different chromatographic purifications, prior to the detection by high resolution instruments. ${ }^{7-11}$ However, this state-of-the-art methodology is time consuming, expensive and requires large amount of organic solvents which often limit the number of samples analyzed in ecotoxicology and risk assessment projects. In this context, we developed a faster and cheaper methodology to conduct different projects at lower cost. This paper presents the PCDD/Fs results obtained by an adapted extraction and digestion method that allows faster preparation at lower expenses.

\section{Materials and Methods}

\section{Materials and standards}

Methylene chloride, toluene, $n$-hexane and isooctane are pesticide grade quality. A mix of seventeen native PCDD/Fs, ${ }^{13} \mathrm{C}$-labeled internal standards were purchased at Wellington Laboratories, Canada. The GC-HRMS system used is a Waters system with an Agilent GC computed with Masslynx 4.1 equipped with a 60 m Agilent J\&W DB-5 column.

\section{Polychlorinated dibenzo- $p$-diox- ins/furans extraction}

Extracts were prepared with $15 \mathrm{~g}$ wet weight of commercial fish (salmon), blue mussels and $9 \mathrm{~g}$ of a certified reference material (CARP-2; Wellington Laboratories). The extraction was performed by a fast and inexpensive extraction in a $50 \mathrm{~mL}$ polypropylene tube with $25-30 \mathrm{~mL}$ of toluene. Tube extraction was performed twice and shaked with a Polytron agitator for $2 \mathrm{~min}$. Extracts were then centrifuged at $3500 \mathrm{rpm}$ for $10 \mathrm{~min}$ and the toluene portion was transferred in a $125 \mathrm{~mL}$ round bottom flask. Toluene was evaporated to about $2 \mathrm{~mL}$ and resuspended with n-hexane to a final volume of $10 \mathrm{~mL}$.

\section{Purification and analysis}

One $\mathrm{ml}$ of this extract is evaporated to dryness for lipid content analysis by gravimetry. The remaining $9 \mathrm{~mL}$ were digested with acid. Three different times of acid digestion were tested on a Heildolph REAX-2 (Rose scientific) shaker, $15 \mathrm{~min}, 2 \mathrm{~h}$ and overnight (16-18 h). Ten mL of concentrated sulphuric acid was added for the $15 \mathrm{~min}$ and $2 \mathrm{~h}$ of shaking, and 15 $\mathrm{mL}$ was added for overnight digestion, which corresponds to the traditional methodology used in the laboratory. Digest extract was centrifuged $10 \mathrm{~min}$ for $15 \mathrm{~min}$ and $2 \mathrm{~h}$ and $45 \mathrm{~min}$ for the overnight test at $3500 \mathrm{rpm}$ to reduce emulsion in the $n$-hexanes portion.
Correspondence: Mélanie Desrosiers, Centre d'expertise en analyse environnementale du Québec, ministère du Développement durable, de l'Environnement et de la Lutte contre les changements climatiques, 2700 Einstein street, Quebec city, QC, Canada, G1P 4P3.

Tel.: 418.643-1301 poste 339 - Fax: 418.528-1091. E-mail: melanie.desrosiers@mddelcc.gouv.qc.ca

Key words: polychlorinated dibenzo- $p$ dioxins/furans, mussels, bioaccumulation.

Conference presentation: ECOBIM meeting, 2014 May, Brest, France.

Acknowledgments: this study is part of a larger collaborative program funded by a Strategic NSERC program, with the support of the Centre d'expertise en analyse environnementale $d u$ Québec (CEAEQ) for chemical analysis. The authors would like to address special thanks to the member of the Division des contaminants industriels organiques of the CEAEQ for their technical assistance.

This work is licensed under a Creative Commons Attribution NonCommercial 3.0 License (CC BYNC 3.0).

(C) Copyright P.-L. Cloutier et al., 2014

Licensee PAGEPress, Italy

Journal of Xenobiotics 2014; 4:4898

doi:10.4081/xeno.2014.4898

Only for the percentage of removal lipid, the residual lipid content was recorded for the $n$ hexanes after the acid digestion by evaporating to dryness to measure the efficiency of the acid digestion for three times evaluated for the lipid purification test only.

For PCDD/Fs analysis, acid digest extracts were purified on a multi-layer column with different silica layer $\left(\mathrm{AgNO}_{3}, \mathrm{NaOH}, \mathrm{H}_{2} \mathrm{SO}_{4}\right)$ from the bottom to top, separated by natural silica layer then fractioned on an alumina column. The purified samples were concentrated to 25 $\mu \mathrm{L}$ and injected on a $60 \mathrm{~m}$ DB5 for the instrumental analysis by GC-HRMS (AgilentWaters).

\section{Results and Discussion}

\section{Lipid purification}

Percentage removal of lipids for three time of digestion evaluated obtained were $90.9 \pm 0.9 \%$ for $15 \mathrm{~min}, 88.4 \pm 12.1 \%$ for $2 \mathrm{~h}$ and $95.2 \pm 6.8 \%$ for overnight digestion. There are no significant differences (one-way ANOVA; $\mathrm{P}>0.25$ ) among $15 \mathrm{~min}, 2 \mathrm{~h}$ and overnight acid digestion. Moreover, the 15 min acid digestion produces less emulsion and better phase partition between the acidic and $n$-hexane portions than the usual overnight acid digestion or $2 \mathrm{~h}$ 
Table 1. Accuracy of the targeted polychlorinated dibenzo-p-dioxins/furans spiked in mussels and salmon.

\begin{tabular}{|c|c|c|c|c|c|c|c|}
\hline PCDD/Fs compounds & $\begin{array}{c}\text { Expected } \\
\text { Values } \\
\text { pg/g }\end{array}$ & $\begin{array}{c}\text { Mussel } \\
\text { salmon } \\
\mathrm{pg} / \mathrm{g}\end{array}$ & $\begin{array}{c}\text { Mussel } \\
\text { spiked } \\
\mathrm{pg} / \mathrm{g}\end{array}$ & $\begin{array}{c}\text { Salmon } \\
\mathrm{pg} / \mathrm{g}\end{array}$ & $\begin{array}{c}\text { Salmon } \\
\text { spiked } \\
\text { pg/g }\end{array}$ & $\begin{array}{c}\text { Accuracy } \\
\text { for mussels (\%) }\end{array}$ & $\begin{array}{l}\text { Accuracy for } \\
\text { salmon }(\%)\end{array}$ \\
\hline 2,3,7,8-TCDF & 1.47 & 0.10 & 1.57 & NDL & 1.44 & $100.3 \%$ & $98.5 \%$ \\
\hline 1,2,3,7,8-PeCDF & 1.30 & NDL & 1.43 & NDL & 1.45 & $110.1 \%$ & $111.8 \%$ \\
\hline 2,3,4,7,8-PeCDF & 1.36 & NDL & 1.36 & NDL & 1.43 & $100.4 \%$ & $105.4 \%$ \\
\hline 1,2,3,4,7,8-HxCDF & 1.31 & NDL & 1.28 & NDL & 1.40 & $97.6 \%$ & $106.9 \%$ \\
\hline $1,2,3,6,7,8-\mathrm{HxCDF}$ & 1.48 & NDL & 1.44 & NDL & 1.44 & $97.6 \%$ & $97.0 \%$ \\
\hline 2,3,4,6,7,8-HxCDF & 1.30 & NDL & 1.26 & NDL & 1.28 & $96.8 \%$ & $98.6 \%$ \\
\hline $1,2,3,7,8,9-\mathrm{HxCDF}$ & 1.31 & NDL & 1.40 & NDL & 1.29 & $107.0 \%$ & $98.4 \%$ \\
\hline 1,2,3,4,6,7,8-HpCDF & 1.36 & NDL & 1.34 & NDL & 1.46 & $98.3 \%$ & $107.1 \%$ \\
\hline 1,2,3,4,7,8,9-HpCDF & 1.19 & NDL & 1.25 & NDL & 1.38 & $104.9 \%$ & $116.0 \%$ \\
\hline OCDF & 2.40 & 0.07 & 2.80 & NDL & 2.67 & $113.5 \%$ & $111.2 \%$ \\
\hline 2,3,7,8-TCDD & 1.29 & NDL & 1.45 & NDL & 1.48 & $112.7 \%$ & $115.1 \%$ \\
\hline 1,2,3,7,8-PeCDD & 1.40 & NDL & 1.34 & NDL & 1.40 & $95.8 \%$ & $100.1 \%$ \\
\hline 1,2,3,4,7,8-HxCDD & 1.41 & NDL & 1.29 & NDL & 1.20 & $91.5 \%$ & $85.2 \%$ \\
\hline 1,2,3,6,7,8-HxCDD & 1.12 & NDL & 1.49 & NDL & 1.43 & $133.7 \%$ & $127.6 \%$ \\
\hline 1,2,3,7,8,9-HxCDD & 1.42 & NDL & 1.34 & NDL & 1.28 & $94.3 \%$ & $90.0 \%$ \\
\hline 1,2,3,4,6,7,8-HpCDD & 1.47 & 0.22 & 1.57 & NDL & 1.46 & $91.8 \%$ & $99.2 \%$ \\
\hline \multirow[t]{4}{*}{ OCDD } & 2.62 & 1.17 & 4.13 & 0.17 & 2.89 & $113.2 \%$ & $104.0 \%$ \\
\hline & & & & & Average & $103.5 \%$ & $104.2 \%$ \\
\hline & & & & & andard deviation & $10.7 \%$ & $10.3 \%$ \\
\hline & & & & & $\%$ RSD & $10.4 \%$ & $9.8 \%$ \\
\hline
\end{tabular}

$\mathrm{PCDD} / \mathrm{Fs}$, polychlorinated dibenzo-p-dioxins/furans.

Table 2. Accuracy of the targeted polychlorinated dibenzo-p-dioxins/furans for the CRM-CARP-2.

\begin{tabular}{|c|c|c|c|}
\hline PCDD/Fs compounds & $\begin{array}{c}\text { CRM-CARP-2 } \\
\mathrm{pg} / \mathrm{g}\end{array}$ & $\begin{array}{l}\text { Certified reference values } \\
\qquad \mathrm{pg} / \mathrm{g}\end{array}$ & $\%$ Accuracy \\
\hline 2,3,7,8-TCDF & 16.014 & $18.2 \pm 1.6$ & $87.99 \%$ \\
\hline 1,2,3,7,8-PeCDF & 7.222 & $5.6 \pm 0.3$ & $128.96 \%$ \\
\hline 2,3,4,7,8-PeCDF & 14.594 & - & \\
\hline $1,2,3,4,7,8-\mathrm{HxCDF}$ & 4.676 & - & \\
\hline $1,2,3,6,7,8-\mathrm{HxCDF}$ & 2.986 & - & \\
\hline 2,3,4,6,7,8-HxCDF & 1.212 & - & \\
\hline $1,2,3,7,8,9-\mathrm{HxCDF}$ & NDL & - & \\
\hline 1,2,3,4,6,7,8-HpCDF & 4.256 & - & \\
\hline 1,2,3,4,7,8,9-HpCDF & NDL & - & \\
\hline OCDF & 0.238 & - & \\
\hline 2,3,7,8-TCDD & 7.662 & $7.4 \pm 0.7$ & $103.54 \%$ \\
\hline 1,2,3,7,8-PeCDD & 4.224 & $5.2 \pm 1.3$ & $81.22 \%$ \\
\hline 1,2,3,4,7,8-HxCDD & 4.147 & $1.6 \pm 0.3$ & $259.17 \%$ \\
\hline $1,2,3,6,7,8-\mathrm{HxCDD}$ & 6.426 & $5.8 \pm 0.8$ & $110.79 \%$ \\
\hline 1,2,3,7,8,9-HxCDD & 0.648 & $0.78 \pm 0.12$ & $83.06 \%$ \\
\hline 1,2,3,4,6,7,8-HpCDD & 7.083 & $6.4 \pm 0.8$ & $110.66 \%$ \\
\hline \multirow[t]{4}{*}{ OCDD } & 9.281 & $9.4 \pm 1.7$ & $98.73 \%$ \\
\hline & Average & $118.24 \%$ & \\
\hline & Standard deviation & $55.01 \%$ & \\
\hline & $\% \mathrm{RSD}$ & $46.53 \%$ & \\
\hline
\end{tabular}

PCDD/Fs, polychlorinated dibenzo-p-dioxins/furans. 
digestion. The 15 min acid digestion allows an easy and fast removal of the lipid content in the extracts and shorter centrifugation time was sufficient at $3500 \mathrm{rpm}$ (10 min against 45 min after overnight digestion).

\section{Polychlorinated dibenzo- $p$-diox- ins/furans analysis}

The tube extraction with 15 min acid digestion shows adequate recovery of the ${ }^{13} \mathrm{C}$ labelled internal standards for the three biological samples targeted, mussels $(70 \% \pm 2 \%)$, salmon $(81 \% \pm 2 \%)$, and the CRM-CARP-2 $(73 \% \pm 2 \%)$

The spiked samples show excellent recovery and accuracy for the targeted PCDD/Fs in mussels (92\% to $133 \%$ with an average of $104 \%)$ and in salmon (85\% to $128 \%$ with an average of 104\%; Table 1).

The CRM-CARP-2 samples show coherent results for most of the targeted PCDD/Fs except for the 1,2,3,4,7,8-HxCDD whose accuracy was problematic and will be investigated (Table 2).

\section{Conclusions}

The tube extraction and the fast acid digestion (15 min) proposed allow an alternative for the monitoring of PCDD/Fs in different biological samples (mussels, salmon and CRM). This innovative method can be done in the same working day compared to the traditional procedure that takes more than 3 days of prepara- tion. With this proposed analytical methodology, the level of solvent consumption is 8 to 10 fold decreased compared to the state-of-art methodology. In the next step, this method will be validated for PCBs and PBDEs analysis in the same type of biological samples with the aim of providing a reliable analytical alternative for monitoring POPs in IPOC related projects.

\section{References}

1. Binelli A, Guzzella L, Roscioli C. Levels and congener profiles of polybrominated diphenyl ethers (PBDEs) in Zebra mussels (D-polymorpha) from Lake Maggiore (Italy). Environ Pollut 2008;153:610-7.

2. Darnerud P0. Toxic effects of brominate flame retardants in man and in wildlife. Environ Int 2003;29:841-53.

3. Covaci A, Gheorghe A, Hulea 0, Schepens P. Levels of organohalogenated pollutants (PCBs, OCPs and PBDEs) in biota from the danube delta, Romania. Organohalogen Compounds 2002;59:9-12.

4. Bervoets L, Voets J, Covaci A, Chu SG, Qadah D, Smolders R, et al. Use of transplanted zebra mussels (Dreissena polymorpha) to assess the bioavailability of microcontaminants in Flemish surface waters. Environ Sci Technol 2005;39:1492-505.

5. Besse JP, Geffard 0, Coquery M. Relevance and applicability of active biomonitoring in continental waters under the Water
Framework Directive. Trac-Trends Anal Chem 2012;36:113-27.

6. Binelli A, Galassi S, Provini A. Factors affecting the use of Dreissena polymorpha as a bioindicator: the PCB pollution in Lake Como (N. Italy). Water Air Soil Pollut 2001;125:19-32.

7. Centre d'expertise en analyse environnementale du Québec. MA.400-BPC 1.0: Détermination des biphényles polychlorés: dosage par chromatographie en phase gazeuse couplée à un spectromètre de masse - méthode par congénère et groupe homologue; 1998, p 41.

8. Centre d'expertise en analyse environnementale du Québec. MA.400 - D.F.1.1: Détermination des dibenzo-para-dioxines polychlorés et dibenzofuranes polychlorés: dosage par chromatographie gazeuse couplée à un spectromètre de masse; 2011, p 33.

9. United States Environmental Protection Agency. Method 8290A: Polychlorinated dibenzo-p-dioxins (PCDDs) and polychlorinated dibenzofurans (PCDFs) by highresolution gas chromatography/high-resolution mass spectrometry (HRGC/HRMS); 2007, p 72.

10. United States Environmental Protection Agency. Method 8082A: Polychlorinated biphenyls (PCBs) by gas chromatography; $2007, \mathrm{p} 56$.

11. United States Environmental Protection Agency. Method 1614: Brominated diphenyl ethers in water soil, sediment and tissue by HRGC/HRMS; 2007, p 87. 